DOI https://doi.org/10.30525/978-9934-26-039-1-10

\title{
РЕДУПЛІКОВАНІ СЛОВА В ІДІОСТИЛІ ЛЕСІ УКРАЇНКИ
}

\author{
Ніколашина T. I. \\ кандидатка філологічних наук, \\ дочентка кафедри украӥнської мови \\ Полтавського начіонального педагогічного університету \\ імені В. Г. Короленка \\ м. Полтава, Украӥна
}

Характерною особливістю індивідуального стилю Лесі Українки $є$ органічне поєднання тонкого ліризму, надзвичайного динамізму, випромінювального позитивізму. Поетеса використовує широкий спектр мовних засобів, серед яких особливе місце займає редупліковані слова як стилістичний засіб організації тексту та експресії.

Редуплікацію досліджували українські мовознавці I. Денисовець, Н. Клименко. А. Нелюба. З. Пахолок, О. Тараненко, Л. Чумак та інші.

Мета наукової розвідки - дослідити редупліковані слова на матеріалі поетичних і драматичних творів Лесі Українки.

Для досягнення цієї мети проаналізовано редупліковані слова, вилучені методом суцільної вибірки із поетичних і драматичних творів Лесі Українки. Обсяг картотеки - понад 60 лексичних одиниць, загалом поетеса активно послуговується іменниковими, прикметниковими, дієслівними, прислівниковими редуплікатами.

Основним методом дослідження $є$ описовий метод і його основні прийоми інвентаризації та систематизації мовних одиниць.

Редуплікація - це свідоме повторення в межах певного мовленнєвого відрізку однієї й тієї ж мовної одиниці 3 певною словотвірною, граматичною, семантичною або стилістичною метою. Семантична універсальність редуплікації як способу творення слів полягає у відтворенні інтенсивності, повторюваності дії, множинності процесів, інтенсивності ознаки, а також міри й кількості. Редуплікація може полягати не тільки в повторі звукового складу редупліката, але й у повторі при антонімії та синонімії, напр.: Ой, здається - не журюся, таки ж я не рада, чогось мені тяжко-важко, на серці досада [2, с. 161].

У сучасній українській мові редупліковані слова складаються найчастіше із двох компонентів i творяться за такими моделями: 1) повний повтор цілого слова дупліканта і дуплікатора: «Subs1-Subs1, Adjec1-Adjec1, Numer1-Numer1, Pron1-Pron1, Verb finitum1-Verb finitum1, Adv1-Adv1, Inter1-Inter1; 2) дивергентне повторення: Adjec1-pref (пре-) 
Adjec1, Adjec1-Adjec2 suf (-ісіньк-), Pron1-Pron2 suf (-ісіньк-), Adv1part(не)-Adv1, Adv1-part(не)-Adv1, Adv1-prep(на)-Adv1, Adv1-Adv2 suf (-ісіньк-), Adv1-Adv2 suf (-еньк-), Adv1- pref (пре-) Adv1»[1, с. 89].

У художніх творах Лесі Українки редупліковані слова складаються найчастіше із двох компонентів: дупліканта i дуплікатора, тому редуплікати з повним повтором цілого слова репрезентують:

1) іменники із конкретним та абстрактним значенням (Subs1-Subs1, Subs1-Subs2), напр.: Куиңю-Куию, поцілуй у руцю! [3, с. 676]; Ну, мирмиром! Поплинем понад виром! [3, с. 346]; На виру-вирочку, на жовтому пісочку, в перловому віночку зав'юся у таночку! [3, с.3 46];

2) якісні прикметники (Adjec1-Adjec1), (Adjec1-pref (пре) Adjec1), наприклад: Чорна-чорна та глибока ніч... [2, с. 276]; Та ще дівочий той шарахван неначеб форемніший, а що жіночий, то такий бахматий та довгий-довгий, мов попівська ряса! [4, с. 513]; За темними борами, та за глибокими морями, та за високими горами, то єсть там дивний-предивний край, де панує ж Урай [3, с. 666];

3) родові та особові дієслівні форми, які увиразнюють інтенсивність, повторюваність дії (Verb1-Verb1), (Verb1-pref (про) Verb1), наприклад: А я дивую, ти з яким лицем збираєшся з'явитися на Вкраїні! Сидів-сидів у запічку московськім, поки лилася кров, поки змагання велося за життя там, на Вкраїні $[4$, с. 554]; А в серці розкішно иявіте-процвітає / Злотистая квітка - надія [2, с. 33];

4) прислівники кількісно-означальні означають дію, стан, ознаку 3 погляду інтенсивності, кількісної градації та репрезентують такі словотвірні моделі Adv1-Adv1, Adv1 -Adv2 suf (-есеньк-), напр.: А дедалі ледве-ледве, мов туман, леліє...[4, с. 221]; I тихо-тихесенько я промовляла: «Сон літньої ночі! Мені тебе жаль!..» [2, с. 56]; Посеред дороги він мало-мало не звернув на бенкет знов до Летіція... [3, с. 78]; Я довго-довго в тую ніч не спала... [3, с. 441];

5) обставинні прислівники часу виражають часову орієнтацію відносно двох рівних частин доби - «дня» і «ночі» (ранкових, вечірніх годин доби), увиразнюють регулярну повторюваність дії чи події або нерегулярну часову повторюваність Adv1-Adv1, Adv1 suf (-есеньк-)Adv2, напр.: I om-om зірватись має / Гостра, злобна епіграма [2, с. 118]; Ранесенько-рано вже зникла рожевая мрія моя...[2, с. 56];

6) редупліковані прислівники виражають певний часовий період життя людини, напр.: ... і винайшов забутий герб якийсь, немовбито вона таки шляхетна ще з дida-nрадiда - чого ж їй ще? [2, с. 395]; Сон, що сниться у неділю рано, / Зроду-звіку не минає дарма [2, с. 185];

7) обставинні прислівники місця виражають просторову локалізацію, вказують на певну фіксовану локалізацію дії або стану в просторі, позначають напрям дії або руху (Adv1-Adv1), напр: Здійметься високо- 
високо в небесні простори / I, може, спітка тую долю [2, с. 30]; ... Слова iï пророчі спопеліли, і вітер їх розніс ген-ген по морю... [2, с. 547]; Де-де! Ще й не такі були дуби, та й тії постинали... [2, с. 701];

8) інтер'єктиви, що походять від іменників (Inter1-Inter1), (Inter1Inter1-Inter2), напр.: Там такий і приспів: «Ой горе-горе, коника забули!» [4, с. 300]; Гай-гай, се необачно, любий друже! [4, с. 56]; I тихенько заспівала: «Люлі-люлі-люлята, засніть мої малята!» [4, с. 633];

9) дієслівні вигуки, що вказують на швидкість, різкість здійснення дії (Inter1-Inter1), напр.: Далі - вже моя робота! Ну! блись-блись! [3, с. 376].

Редупліковані слова в художньому тексті дозволяють передати більший обсяг інформації як змістової, так і емоційно-оцінної, експресивної, увиразнити внутрішній світ і психоемоційний стан героїв, а також слугують для створення зорових та слухових образів. Редупліковані іменники, прикметники, дієслова, прислівники, вигуки уможливлюють ритмічність, римованість, експресивність поетичного та драматичного твору.

\title{
Література:
}

1. Ніколашина Т. Редуплікати в сучасній українській мові: структура, семантика, функція. Studia Ucrainica Varsoviensia 5. Warszawa : Wydawnictwa Uniwersytetu Warszawskiego, 2017. C. 87 - 101.

2. Українка Леся. Твори : В 2 т. Т. 1 : Поетичні твори; Драматичні твори. К. : Наук. думка, 608 с.

3. Українка Леся. Твори : В 2. Т. 2 : Драматичні твори К. : Наук. думка, 728 с.

4. Українка Леся. Драматичні твори. К. : Дніпро, 1989. 762 с.

DOI https://doi.org/10.30525/978-9934-26-039-1-11

\section{СЕМАНТИЧНА СТРУКТУРА ЛЕКСЕМ ЗДОРОВИЙ / ЗДРАВ В УКРАЇНСЬКІЙ ТА СЕРБСЬКІЙ МОВАХ}

\author{
Новак О. М. \\ кандидат філологічних наук, \\ дочент кафедри загального та слов'янського мовознавства \\ Одеського національного університету імені I. І. Мечникова \\ м. Одеса, Україна
}

Лексема «здоровий» має спільнослов'янське походження, проте в сучасних слов'янських мовах іiі структура та обсяг значення широко 